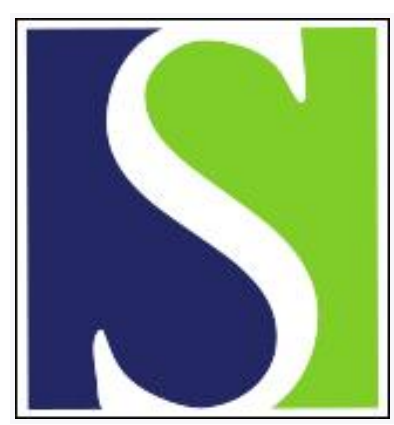

Scand J Work Environ Health 1983;9(5):397-403

https://doi.org/10.5271/sjweh.2394

Issue date: Oct 1983

Elimination of chromium in urine after stainless steel welding.

by Welinder $\mathrm{H}$, Littorin M, Gullberg B, Skerfving S

This article in PubMed: www.ncbi.nlm.nih.gov/pubmed/6673098

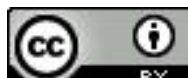




\title{
Elimination of chromium in urine after stainless steel welding
}

\author{
by Hans Welinder, PhD, ${ }^{1}$ Margareta Littorin, MD, ${ }^{1}$ Bo Gullberg, BS, ${ }^{2}$ \\ Staffan Skerfving, MD ${ }^{1}$
}

\begin{abstract}
WELINDER H, LITTORIN M, GULLBERG B, SKERFVING S. Elimination of chromium in urine after stainless steel welding. Scand $j$ work environ health 9 (1983) $397-403$. Nine retired (on an average of four years) stainless steel welders had higher $(\mathrm{p}<0.001)$ urinary chromium levels [mean 7 (range $3-13$ ) $\mu \mathrm{mol} / \mathrm{mol}$ of creatinine] than 21 nonexposed referents [mean $\leq 1.5$ (range $<0.6-7$ ) $\mu \mathrm{mol} / \mathrm{mol}$ of creatinine] but did not differ in this respect from 14 active welders studied at the end of a 31-d vacation (mean 9 , range $4-17$ ). This result shows the existence of a slow compartment for chromium in the body. Urinary chromium on time after the end of exposure was analyzed mathematically by use of an exponential two-compartment model. Good fits were obtained, showing the existence of a fast compartment in addition to the slow one. For four welders followed for $31 \mathrm{~d}$, the biological half-time of the slow compartment ranged from $14 \mathrm{~d}$ to infinity. For 12 welders followed for $60 \mathrm{~h}$, the fast compartment had a median half-time of 7 (range 4-35) h. For 19 welders there was a significant $(p<0.01)$ correlation between chromium in air (total and soluble hexavalent) and urinary chromium $\left(r_{S}=0.68\right.$ and 0.64$)$. However, the variation of urinary chromium on chromium in air was considerable, especially at chromium air levels at or below the hygienic standards. Correction for urinary chromium levels on Monday morning did not decrease the variation.
\end{abstract}

Key terms: air, biological half-time, biological monitoring, kinetics.

Exposure to chromium and chromates is common in many work environments, eg, in stainless steel welding, in chromate pigment production, and in electroplating industries. Exposure to hexavalent chromium may cause serious health effects, eg, eczema, asthma, and bronchial cancer. In stainless steel manual metal arc welding the fumes contain chromium, $50-100 \%$ of which is hexavalent and water soluble (15).

To measure the exposure to chromium during welding operations is tedious and time-consuming. Thus biological monitoring of exposure would be preferable. Chromium levels in urine have been rather extensively employed for this purpose (4, $8,10,15)$. However, good biological monitoring requires knowledge of the kinetics of the parameter studied. It is thus a major

1 Department of Occupational Medicine, University Hospital, S-221 85 Lund, Sweden.

2 Regional Tumour Registry, University Hospital, S-221 85 Lund, Sweden.

Reprint requests to: $\mathrm{Dr} \mathrm{H}$ Welinder, Department of Occupational Medicine, University Hospital, S-221 85 Lund, Sweden. drawback that information on the kinetics of chromium elimination in urine is limited (16).

In the present communication we report a study on the kinetics of chromium elimination in the urine of stainless steel welders.

\section{Material and methods}

\section{Subjects}

Three different groups of male stainless steel manual metal arc welders were studied. Most of the men had also used metal inert gas and tungsten inert gas equipment.

Group 1 consisted of 20 welders [mean age 44 (range 33-64) years, mean exposure time 20 (range 7-41) years]. Urine samples were obtained from these men on Friday after work and on Monday morning before work. Then all the urine voided was collected until Tuesday morning before work (fig 1). Air sampling was performed during the workhours on Monday. 
Group 2 comprised 14 welders [mean age 40 (range 29-64) years, mean exposure time 13 (range 2-41) years]. Urine samples were obtained twice, after work before four weeks of vacation and before work after the end of vacation. For four subjects urine samples were also obtained after $2.5,10$, and $17 \mathrm{~d}$ of vacation.

Nine retired welders [mean age 68 (range 63-76) years, mean exposure time 35 (range 22-45) years, mean time after end of exposure 4.5 (range 1-10) years] made up group 3 , from which urine samples were also obtained.

Urine samples were obtained from 21 male referents [mean age 43 (range 32-60) years] without occupational chromium exposure. These subjects were matched to group 1 for age and living area. Detailed information on occupations has been given elsewhere (6).

\section{Medical examinations}

No evidence of significant disease, except for hypertension in two persons (one welder and one referent), was revealed by medical history and biochemical examinations (including liver and kidney tests).

\section{Chromium in urine}

Urine samples were collected in acidwashed bottles. Before storage and analysis $100 \mu \mathrm{l}$ of concentrated nitric acid was added to $10 \mathrm{ml}$ of urine. The analyses were performed (sometimes after dilution) by use of direct electrothermal atomic absorption spectrometry (Perkin Elmer AAS 5000 , HGA 500 and autosampling system AS 40). The working detection limit was $0.008 \mu \mathrm{mol} / \mathrm{l}$. The accuracy of the method was confirmed by good results in interlaboratory checks. The method error, as calculated from double analyses on different days, was $0.021,0.08,0.09$ and 0.14 $\mu \mathrm{mol} / \mathrm{l}$, respectively, for the following intervals: $0-0.19,0.20-0.57,0.58-1.90$, and $>1.90 \mu \mathrm{mol} / \mathrm{l}$.

Urinary chromium was related to the urinary creatinine levels, which were determined by a spectrophotometric method (13).

\section{Chromium in air}

In welder group 1 the individual exposure was determined in samples collected on filters (Millipore AAWP 037; pore diameter $0.8 \mu \mathrm{m}$ ) with a portable pump (Mine Safety Appliances Co or Casella; $21 / \mathrm{min}$ ) in the breathing zones. The filters were divided into two identical parts. From one half the total chromium level was analyzed by atomic absorption spectrometry after the filter was treated with aqua regia and diluted with deionized water. The other half of the filter was analyzed for water-soluble hexavalent chromium by atomic absorption spectrometry after extraction with deionized water and centrifugation.

\section{Mathematical analysis}

The data on the urinary chromium levels were analyzed for the kinetics of elimination. First the mean of the referents (1.5 $\mu \mathrm{mol} / \mathrm{mol}$ of creatinine) was subtracted. Then the chromium in the urine of the four welders in group 2 who were studied for $31 \mathrm{~d}$ was analyzed with the use of a twocompartment model. A computer fitted the sum of two exponential functions of urinary chromium on time, using the least square method, to the data for each individual.

Twelve subjects, for whom all urine voided Monday afternoon through Tuesday morning was obtained and for whom the difference between the urinary chromium level on Monday afternoon and Monday morning was $\geq 7 \mu \mathrm{mol} / \mathrm{mol}$ of creatinine (ie, they were significantly exposed), were selected for further analysis.

Then a new mathematical analysis was performed in which the sum of two exponential functions was fitted to the urinary chromium data from Monday afternoon to Tuesday morning. The time corresponding to each urinary chromium value was set to the center of the interval during which the urine portion was collected. We used the center of the sampling periods because the chromium concentrations in the urine produced in the kidney decreased during each sampling period. For the slow compartment a biological half-time identical with that determined for the four welders just discussed was assumed. 
Now the data on the urinary chromium level on Friday afternoon could be fitted to this preliminary curve. Thus the urinary chromium level on Monday morning could also be used (fig 1). Including these values, a new set of calculations of a decay curve (still using the assigned value for the halftime of the slow compartment) was performed. Thus the half-time for the fast compartment and the $\mathrm{Y}$ intercepts for the fast and the slow compartments were obtained.

The fit of the model to the observed values was expressed as the percentage of the total variance explained by the calculated curve.

\section{Results}

The referents had a mean urinary chromium level of $\leq 1.5 \mu \mathrm{mol} / \mathrm{mol}$ of creatinine (table 1 ). The retired welders had a mean level of $7 \mu \mathrm{mol} / \mathrm{mol}$ of creatinine, a value significantly higher than that of the referents $(p<0.001$, two-tailed; MannWhitney $U$ test). The latter did not differ $(p>0.1)$ from that of welders studied after the end of their vacation, the mean level for whom was $9 \mu \mathrm{mol} / \mathrm{mol}$ of creatinine.

There was no significant correlation between exposure time (welding years) and the urinary chromium level, neither for active welders (Monday morning or after vacation) nor for retired ones.

In all but one of the 14 welders in group 2 there was a decrease in urinary chromium during the vacation, the mean changing from 45 to $9 \mu \mathrm{mol} / \mathrm{mol}$ of creatinine $(\mathrm{p}<0.005$, one-tailed; Wilcoxon matched-pairs signed-ranks test). In addi- tion, there were significant decreases in group 1 from Friday afternoon to Monday morning (means 34 versus $19 \mu \mathrm{mol} / \mathrm{mol}$ of creatinine; $\mathrm{p}<0.005$, one-tailed), as well as from Monday afternoon to Tuesday morning (means 45 versus $33 \mu \mathrm{mol} / \mathrm{mol}$ of creatinine; $p<0.01$, one-tailed).

Thus the data indicated a rapid initial decrease in the urinary chromium level after the end of exposure, and probably a considerably slower (if any) change later on. To elucidate this further, the elimination pattern was studied more closely during the vacations of a subsample of four welders from group 2. The half-time of the slow compartment was infinite for two subjects, $33 \mathrm{~d}$ for one, and $14 \mathrm{~d}$ for one (fig 2). Thus, as suggested by the data

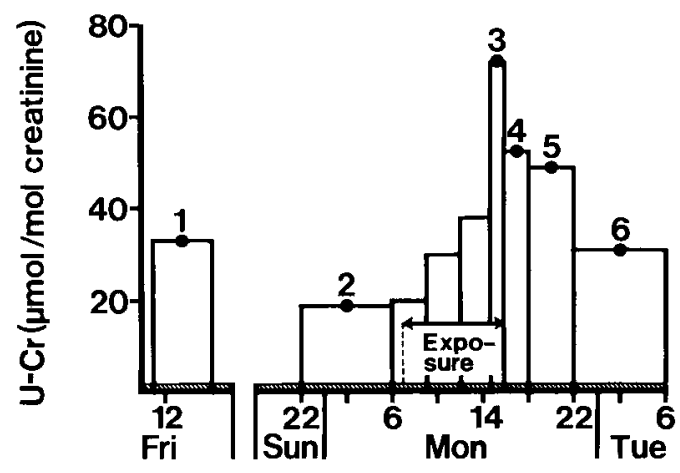

Time of urine sampling

Fig 1. Chromium levels in the urine (U-Cr) of welder 6 during and after welding stainless steel. The bars indicate urine sampling time and the level in the sample; the numbered circles are the times and levels used in further calculations, and the shaded area indicates the urinary chromium level of the referents.

Table 1. Chromium levels in the urine (U-Cr) of 34 active (groups 1 and 2) and 9 retired (group 3) welders and 21 referents.

\begin{tabular}{|c|c|c|c|c|}
\hline & \multicolumn{2}{|c|}{$\begin{array}{l}\text { Exposure- } \\
\text { free period }\end{array}$} & \multicolumn{2}{|c|}{$\begin{array}{c}\mathrm{U}-\mathrm{Cr} \\
(\mu \mathrm{mol} / \mathrm{mol} \text { of creatinine) }\end{array}$} \\
\hline & Mean & Range & Mean & Range \\
\hline \multicolumn{5}{|l|}{ Group 1} \\
\hline $\begin{array}{l}\text { Friday after work }(N=19) \\
\text { Monday before work }(N=20) \\
\text { Tuesday before work }(N=20)\end{array}$ & $\begin{array}{rl}0 & \mathrm{~h} \\
60 & \mathrm{~h} \\
11 \mathrm{~h}\end{array}$ & $\begin{array}{r}- \\
56-65 h \\
8-12 h\end{array}$ & $\begin{array}{l}34 \\
19 \\
33\end{array}$ & $\begin{array}{l}4-112 \\
2-62 \\
2-98\end{array}$ \\
\hline \multicolumn{5}{|l|}{ Group 2} \\
\hline $\begin{array}{l}\text { Before vacation }(N=14) \\
\text { After vacation }(N=14)\end{array}$ & $\begin{array}{rl}0 & h \\
31 & d\end{array}$ & $\overline{-}$ & $\begin{array}{r}45 \\
9\end{array}$ & $\begin{array}{l}5-141 \\
4-17\end{array}$ \\
\hline Group $3(N=9)$ & 4 years & $1-10$ years & 7 & $3-13$ \\
\hline Reference group $(\mathrm{N}=21)$ & - & - & $\leq 1.5$ & $<0.6-7$ \\
\hline
\end{tabular}


Table 2. Determinations of chromium in the urine (U-Cr) ( $\mu \mathrm{mol} / \mathrm{mol}$ of creatinine) of 12 welders.

\begin{tabular}{|c|c|c|c|c|c|c|c|}
\hline \multirow{2}{*}{ Subject } & & \multirow{2}{*}{ Fridayb } & \multicolumn{4}{|c|}{ Monday } & \multirow[b]{2}{*}{ Tuesday } \\
\hline & & & Sample $1^{a}$ & Sample $2^{b}$ & Sample $3^{b}$ & Sample $4^{b}$ & \\
\hline Welder & 1 & & & & & & \\
\hline $\begin{array}{r}\text { Time } \\
\text { U-Cr } \\
\text { Welder }\end{array}$ & 2 & $\begin{array}{l}1450 \\
42\end{array}$ & $\begin{array}{l}0545 \\
20\end{array}$ & $\begin{array}{l}1645 \\
38\end{array}$ & $\begin{array}{l}2350 \\
28\end{array}$ & $\begin{array}{l}. . \\
. .\end{array}$ & $\begin{array}{l}0500 \\
34\end{array}$ \\
\hline $\begin{array}{r}\text { Time } \\
\text { U-Cr } \\
\text { Welder }\end{array}$ & 3 & $\begin{array}{l}1540 \\
25\end{array}$ & $\begin{array}{l}0530 \\
15\end{array}$ & $\begin{array}{l}1800 \\
53\end{array}$ & $\begin{array}{l}2130 \\
30\end{array}$ & $\begin{array}{l}. . \\
.\end{array}$ & $\begin{array}{l}0530 \\
37\end{array}$ \\
\hline $\begin{array}{r}\text { Time } \\
\text { U-Cr } \\
\text { Welder }\end{array}$ & 4 & $\begin{array}{l}1700 \\
84\end{array}$ & $\begin{array}{l}0600 \\
35\end{array}$ & $\begin{array}{l}1700 \\
114\end{array}$ & $\begin{array}{l}2210 \\
69\end{array}$ & $\begin{array}{l}. . \\
\cdots\end{array}$ & $\begin{array}{l}0600 \\
73\end{array}$ \\
\hline $\begin{array}{r}\text { Time } \\
\text { U-Cr } \\
\text { Welder }\end{array}$ & 5 & $\begin{array}{l}1435 \\
19\end{array}$ & $\begin{array}{l}0330 \\
17\end{array}$ & $\begin{array}{l}1650 \\
85\end{array}$ & $\begin{array}{l}2130 \\
63\end{array}$ & $\begin{array}{l}. . \\
.\end{array}$ & $\begin{array}{l}0600 \\
46\end{array}$ \\
\hline $\begin{array}{c}\text { Time } \\
\text { U-Cr } \\
\text { Welder }\end{array}$ & 6 & $\begin{array}{l}1645 \\
36\end{array}$ & $\begin{array}{l}0530 \\
17\end{array}$ & $\begin{array}{l}1545 \\
51\end{array}$ & $\begin{array}{l}1815 \\
47\end{array}$ & $\begin{array}{l}. . \\
. .\end{array}$ & $\begin{array}{l}0530 \\
37\end{array}$ \\
\hline $\begin{array}{r}\text { Time } \\
\text { U-Cr } \\
\text { Welder }\end{array}$ & 7 & $\begin{array}{l}1615 \\
33\end{array}$ & $\begin{array}{l}0600 \\
19\end{array}$ & $\begin{array}{l}1545 \\
72\end{array}$ & $\begin{array}{l}1800 \\
55\end{array}$ & $\begin{array}{l}2200 \\
49\end{array}$ & $\begin{array}{l}0600 \\
31\end{array}$ \\
\hline $\begin{array}{r}\text { Time } \\
\text { U-Cr } \\
\text { Welder }\end{array}$ & 8 & $\begin{array}{l}1205 \\
29\end{array}$ & $\begin{array}{l}0540 \\
17\end{array}$ & $\begin{array}{l}1745 \\
24\end{array}$ & $\begin{array}{l}2250 \\
19\end{array}$ & $\begin{array}{l}\cdots \\
\cdots\end{array}$ & $\begin{array}{l}0620 \\
17\end{array}$ \\
\hline $\begin{array}{r}\text { Time } \\
\text { U-Cr } \\
\text { Welder }\end{array}$ & 9 & $\begin{array}{l}1500 \\
112\end{array}$ & $\begin{array}{l}0600 \\
62\end{array}$ & $\begin{array}{l}1600 \\
131\end{array}$ & $\begin{array}{l}1800 \\
121\end{array}$ & $\begin{array}{l}2030 \\
93\end{array}$ & $\begin{array}{l}0600 \\
74\end{array}$ \\
\hline $\begin{array}{r}\text { Time } \\
\text { U-Cr } \\
\text { Welder }\end{array}$ & 10 & $\begin{array}{l}1500 \\
48\end{array}$ & $\begin{array}{l}0600 \\
30\end{array}$ & $\begin{array}{l}1700 \\
37\end{array}$ & $\begin{array}{l}2200 \\
31\end{array}$ & $\begin{array}{l}. \\
.\end{array}$ & $\begin{array}{l}0500 \\
28\end{array}$ \\
\hline $\begin{array}{r}\text { Time } \\
\text { U-Cr } \\
\text { Welder }\end{array}$ & 11 & $\begin{array}{l}1800 \\
42\end{array}$ & $\begin{array}{l}0600 \\
21\end{array}$ & $\begin{array}{l}1800 \\
160\end{array}$ & $\begin{array}{l}2100 \\
119\end{array}$ & $\begin{array}{l}. . \\
.\end{array}$ & $\begin{array}{l}0600 \\
98\end{array}$ \\
\hline $\begin{array}{r}\text { Time } \\
\text { U-Cr } \\
\text { Welder }\end{array}$ & 12 & $\begin{array}{l}1600 \\
84\end{array}$ & $\begin{array}{l}0600 \\
31\end{array}$ & $\begin{array}{l}1800 \\
54\end{array}$ & $\begin{array}{l}2200 \\
44\end{array}$ & $\begin{array}{l}. . \\
. .\end{array}$ & $\begin{array}{l}0600 \\
38\end{array}$ \\
\hline $\begin{array}{l}\text { Time } \\
\text { U-Cr }\end{array}$ & & $\begin{array}{l}1600 \\
13\end{array}$ & $\begin{array}{l}0500 \\
8\end{array}$ & $\begin{array}{l}1800 \\
20\end{array}$ & $\begin{array}{l}2200 \\
19\end{array}$ & .. & $\begin{array}{l}0600 \\
10\end{array}$ \\
\hline
\end{tabular}

a Before work.

b After work.

Table 3. Kinetics of the elimination of chromium in the urine $(\mathrm{U}-\mathrm{Cr})$ of welders after welding stainless steel. A two-compartment model was employed. The biological half-time of the slow compartment was assumed to be infinite.

\begin{tabular}{lccc}
\hline Subject & $\begin{array}{c}\text { Half-time } \\
\text { of the fast } \\
\text { compartment } \\
\text { (h) }\end{array}$ & $\begin{array}{c}\text { Fraction of } \\
\text { initial U-Cr } \\
\text { in the slow } \\
\text { compartment } \\
(\%)\end{array}$ & $\begin{array}{c}\text { Fraction of } \\
\text { total variance } \\
\text { explained by } \\
\text { the curve } \\
(\%)\end{array}$ \\
\hline Welder 1 & 35 & 26 & 88 \\
Welder 2 & 10 & 31 & 77 \\
Welder 3 & 7 & 34 & 84 \\
Welder 4 & 7 & 17 & 99 \\
Welder 5 & 12 & 30 & 99 \\
Weider 6 & 5 & 25 & 98 \\
Welder 7 & 5 & 70 & 96 \\
Welder 8 & 4 & 45 & 97 \\
Welder 9 & 6 & 82 & 94 \\
Welder 10 & 9 & 11 & 91 \\
Welder 11 & 9 & 57 & 99 \\
Welder 12 & 5 & 31 & 91 \\
\hline Median & 7 & 31 & 95 \\
\hline
\end{tabular}

already given, after the initial decay, the level changed only very slowly.

In 12 subjects (group 1) the pattern of initial decay was studied more closely (fig
$1 \& 3$, table 2). Now an assigned half-time of infinite length was applied for the slow compartment on the basis of the data obtained for the four subjects studied during vacation, which means that for this particular choice the model is identical with a one-compartment model with a constant. The median half-time of the fast compartment was 7 (range $4-35$ ) h (table 3 ). The fit of the observed levels on time was close to the model.

The slow compartment corresponded to a median of 31 (range $11-82$ ) \% of the levels measured at the end of work for the 12 welders whose data were analyzed mathematically.

There were significant $(\mathrm{p}<0.01)$ correlations between chromium in air on the one hand-both total chromium (fig 4$)(r=0.86$, linear correlation; $r_{S}=0.68$, Spearman rank correlation coefficient) and soluble hexavalent chromium $\left(r=0.79 ; r_{S}^{-}=0.64\right)$ - and urinary chromium on the other for 
19 welders (group 1). However, below air levels of $100 \mu \mathrm{g} / \mathrm{m}^{3}$, the variation was great.

Due to the rapid decay of the first compartment, the levels measured on Monday morning should mainly reflect the slow compartment. Indeed our chemically analyzed data on the urinary chromium levels for Monday morning were close to the ones calculated with the model (median difference $1.2 \mu \mathrm{mol} / \mathrm{mol}$ of creatinine, range $0.1-9.4 \mu \mathrm{mol} / \mathrm{mol}$ of creatinine). A hypothesis that the difference between levels at the end of work (fast and slow compartment) and levels on Monday morning (slow compartment) does reflect the exposure during the day was tested for 19 welders (group 1, fig 4). There was a significant correlation between total chromium levels in the air and urine $\left(\mathrm{r}=0.89, \mathrm{r}_{\mathrm{S}}=0.59\right.$, $\mathrm{p}<0.01$ ). However, at chromium air levels below $100 \mu \mathrm{g} / \mathrm{m}^{3}$, there was a considerable variation in urinary chromium on chromium in air. The use of soluble hexavalent chromium in air instead of total chromium did not improve the picture (not shown in fig 4).

\section{Discussion}

The main findings of the present study were the following: (i) the elimination pattern of chromium in urine after exposure to fumes from stainless steel welding was well described by a two-compartment model with at least one fast compartment, with a half-time of a few hours, and one slow one, with a half-time of weeks to years, and (ii) there was a positive correlation between chromium in the air and urine, but the air chromium levels could not be deduced accurately from the urinary chromium value at low levels.

We chose to perform the analysis using a two-compartment model. This approach gave a good fit for the available data. It is quite clear that there is a fast compartment. In addition the data obtained for the welders studied during vacation and for retired welders showed that there is at least one much slower compartment. However the available limited information in terms of number of subjects and measurements of urinary chromium levels, as well as the short observation periods, does not allow firm conclusions on whether inter-

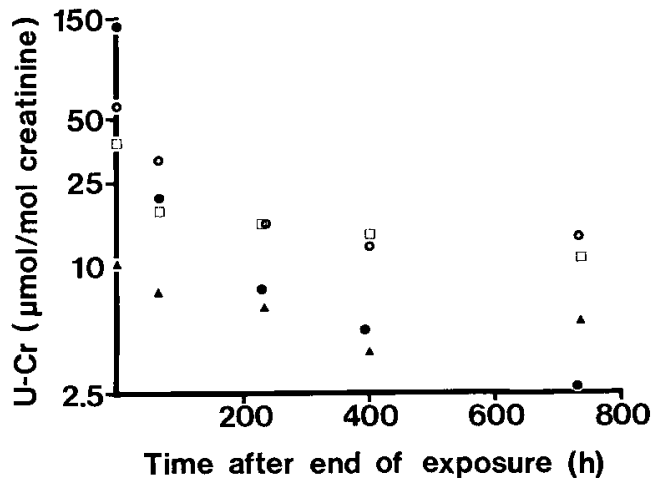

Fig 2. Decrease of chromium in the urine $(\mathrm{U}-\mathrm{Cr})$ of four welders during vacation.

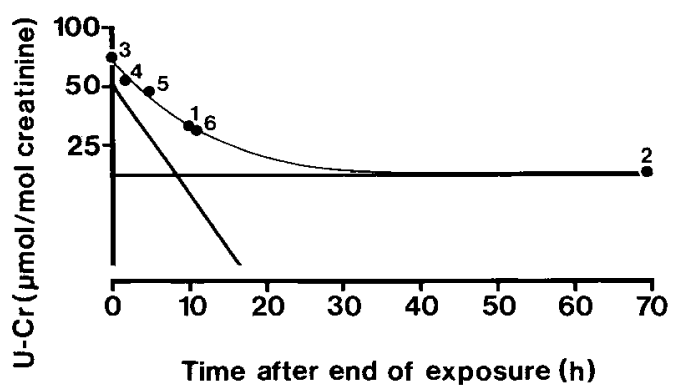

Fig 3. Chromium levels in the urine (U-Cr) of welder 6 after welding stainless steel. The numbers of the dots correspond with the numbers on the bars of fig 1. Elimination curves based on a two-compartment model are shown. The biological halftime of the slow compartment was assumed to be infinite.

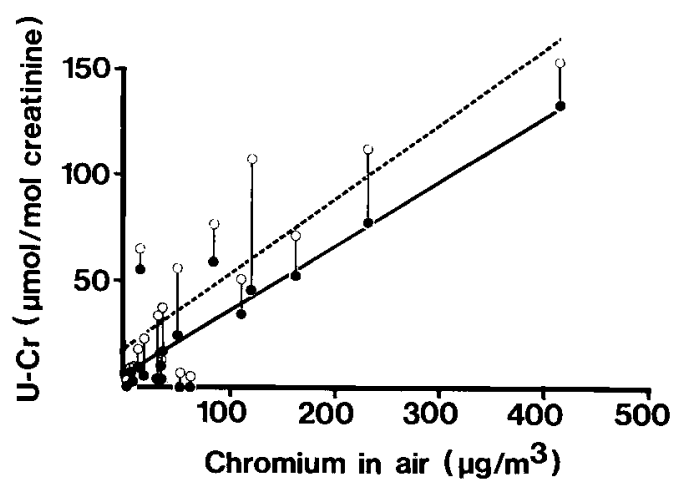

Fig 4. Relation between the time-weighted average levels of total chromium in the air during $1 \mathrm{~d}$ of welding stainless steel and the levels of chromium in the urine $(\mathrm{U}-\mathrm{Cr})$ of 19 welders at the end of the workday (open circles). Closed circles denote $\mathrm{U}-\mathrm{Cr}$ when the Monday morning level has been subtracted. The regression equations were $Y=0.36 \mathrm{X}$ +16 for the uncorrected values (broken line) and $Y=0.31 X+3.8$ for corrected ones (solid line). 
mediate compartments exist, although the short half-time of the second compartment observed for two of the welders studied during vacation might indicate the presence of one or more additional pools. Indeed, in the rat, the excretion of trivalent chromium follows a three-compartment pattern (7). The weiders' pattern of accumulation/elimination followed for one (15) or four (8) weeks may also indicate the presence of a middle compartment with a half-time of a few days.

The available data do not allow detailed conclusions about the half-time of the slow compartment. Thus the data on welders on vacation are too few and the vacation period too short. Neither do we know what the level of urinary chromium was for the retired welders at the end of work. However, it is quite clear that the elimination rate is very slow; there is at least one pool with a half-time of weeks to years. Observations by Mutti et al (8), on elevated chromium levels in welders three weeks after the end of exposure, are also in agreement with a compartment with a slow elimination rate.

The rate of elimination from the slow pool could not be estimated for the welders studied only Friday afternoon through Tuesday morning. Thus, for this compartment, we had to select a half-time from the other information available. We chose infinity. Of course it could not be infinite in reality. However, the choice affected the estimate of the half-time of the fast compartment very little whether an infinite half-time for the slow compartment was applied or whether one of years, months, or even weeks had been used.

To get a good picture of the last part of elimination of the fast compartment, data collected on Friday afternoon and Monday morning were used in combination with data obtained for the same individual Monday afternoon through Tuesday morning. There is no reason to believe that the elimination pattern Friday-Monday should differ from that of Monday-Tuesday as we found no systematic variation in the halftime of the fast compartment on the highest urinary chromium levels measured. The operation performed thus seems justifiable.

There are a couple of other possible sources of error as regards the estimation of the decay rates of the fast compartment.
The observations from each subject are few. In addition there is an analytical error in each observation. However at least the median should be fairly accurate.

The median half-time of $7 \mathrm{~h}$ for the fast compartment is shorter than the $13-38 \mathrm{~h}$ registered earlier by a Finnish group (16) who studied four welders. These authors applied a linear one-compartment model and a background level, a procedure identical to our use of a two-compartment model with an infinite half-time for the slow compartment. Their Monday morning levels were similar to ours, but they employed lower background levels (the arrival at which is not obvious from their paper). In addition they used the urinary chromium level at the end of work, not as in the present study, the highest level, which was mostly found some hours after the end of exposure. Both these differences tend to give too long a half-time for the Finnish welders.

The variation in the fast-compartment half-time between individuals is interesting in light of the interindividual variations in excretion patterns for other heavy metals, eg, methylmercury (11), cadmium (18), and lead (9). However the uncertainty in our individual estimates is too great to allow firm conclusions on the size of interindividual differences in excretion patterns and associated variation in risks at exposure.

As a result of the elimination of the slow compartment, the retired welders must have excreted several milligrams of chromium after the end of exposure. Data on analyses of autopsy material from chromium-exposed workers $(2,14,17)$ indicate that no organ but the lung contains such large amounts. Thus the lung is probably the location of the slow compartment. This assumption is supported by studies made by Kalliomäki et al (5), who found positive correlations between the remanent magnetic field of the chest area, chromium exposure, and the urinary chromium level of stainless steel welders.

As the urinary chromium level on Monday morning probably mainly reflects the slow compartment, it might perhaps be useful as an integrated dose index in the biological monitoring of exposure. However we were not able to show a correlation to exposure time among welders. This 
lack may be due to variations in exposure intensity or elimination kinetics.

Like other workers $(8,10,15)$, we found a correlation between chromium in the air and urine. However, at air levels at or below the hygienic standards [Sweden $20 \mu \mathrm{g} / \mathrm{m}^{3}$ (12), USA $50 \mu \mathrm{g} / \mathrm{m}^{3}$ (1)], the variation had a magnitude making urinary chromium an imprecise tool for biological monitoring. Neither subtraction of the Monday morning background urinary chromium levels, nor the use of soluble hexavalent chromium in the air only, decreases this variation. Again, the interindividual variation in elimination kinetics may have contributed.

As to the biological monitoring of risk by following the urinary chromium levels, not much is known. Franchini et al (3) briefly mentioned slight effects on kidneys in welders, but unfortunately did not give the urinary chromium levels. In our welders neither genotoxic effects (6) nor kidney damage could be demonstrated.

\section{Acknowledgments}

We wish to express our thanks to the workers, the personnel of the health care units, and the management of the factories studied. Ms K Lindholm, Ms A-P Foyntidakis, and Ms G Lennartsson have given valuable technical assistance.

\section{References}

1. American Conference of Governmental Industrial Hygienists. Threshold limit values for chemical substances and physical agents in the workroom environment with intended changes for 1981. Cincinnati, OH 1981.

2. Baetjer AM, Damrou C, Budacz V. The distribution and retention of chromium in men and animals. Arch ind health 20 (1959) $136-150$.

3. Franchini I, Mutti A, Cavatorta A, Corradi A, Cosi A, Olivetti G, Borghetti A. Nephrotoxicity of chromium. Contrib nephrol 10 (1978) 90-110.

4. Gylseth B, Gundersen N, Langård S. Evaluation of chromium exposure based on a simplified method for urinary chromium determination. Scand j work environ health 3 (1977) 28-31.
5. Kalliomäki PL, Rahkonen E, Vaaranen V, Kalliomäki K, Aittoniemi K. Lung retained contaminants, urinary chromium and nickel among stainless steel welders. Int arch occup environ health 49 (1981) 67-75.

6. Littorin M, Högstedt B, Strömbäck B, Karlsson A, Welinder $\mathrm{H}$, Mitelman $\mathrm{F}$, Skerfving S. No cytogenetic effects in lymphocytes of stainless steel welders. Scand j work environ health 9 (1983) 259-264.

7. Mertz W, Roginski EE, Reba RC. Biological activity and fate of trace quantities of intravenous chromium (III) in the rat. Am $\mathrm{j}$ physiol 209 (1965) 489-494.

8. Mutti A, Cavatorta A, Pedroni C, Borghi A, Giavoli A, Franchini I. The role of chromium accumulation in the relationship between airborne and urinary chromium in welders. Int arch occup environ health 43 (1976) $123-133$.

9. Schütz A, Skerfving S, Gullberg B. Elimination of lead from blood after end of exposure. Presented at the XX International Congress on Occupational Health, Cairo, 25 September-1 October 1981.

10. Sjögren B. Arbetsmiljö 13. Relationer mellan luft- och urinhalter av fluorider, krom och nickel vid svetsning. Arbetarskyddsverket, Stockholm 1981. (Arbete och hälsa 1981: 9).

11. Skerfving S. Methylmercury exposure, mercury levels in blood and hair, and health status in Swedes consuming contaminated fish. Toxicology 2 (1974) 3-23.

12. Swedish National Board of Occupational Safety and Health. Hygieniska gränsvärden. Stockholm 1981.

13. Teger-Nilsson AC. Serum creatinine determinations using an ion exchange resin. Scand $\mathrm{j}$ cl in lab invest 13 (1961) 323-331.

14. Teraoka $\mathrm{H}$. Distribution of 24 elements in the internal organs of normal males and the metallic workers in Japan. Arch environ health 36 (1981) 155-164.

15. Tola S, Kilpiö J, Virtamo M, Haaga K. Urinary chromium as an indicator of the exposure of welders to chromium. Scand $j$ work environ health 3 (1977) 192-202.

16. Tossavainen A, Nurminen M, Mutanen $P$, Tola S. Application of mathematical modelling for assessing the biological half-times of chromium and nickel in field studies. $\mathrm{Br} \mathrm{j}$ ind med 37 (1980) 285-291.

17. Tsuneta $Y$, Ohsaki $Y$, Kimura K, Mikami H, Abe S, Murao M. Chromium content of lungs of chromate workers with lung cancer. Thorax 35 (1980) 294-297.

18. Welinder $\mathrm{H}$, Skerfving $\mathrm{S}$, Henriksen $\mathrm{O}$. Cadmium metabolism in man. Br $\mathrm{j}$ ind med 34 (1977) $221-228$.

Received for publication: 29 October 1982 